\title{
The Updating of the Nautical Chart Number 69 on Java Sea Area for Safety Navigation of Sailing
}

\author{
Dwi Septri Hastuti, Bambang Kun Cahyono \\ Department of Geodetic Engineering, Universitas Gadjah Mada, INDONESIA.
}

\section{Article History:}

Received 25 October 2018

Received in revised form 20 December 2018

Accepted 27 December 2018

Available online 31 January 2019

\section{Keywords:}

Nautical Charts, Updating, Safety Navigation, Java Sea.

\section{Corresponding Author:}

Dwi Septri Hastuti

Email: dwiseptrihastuti@gmail.com

Bambang Kun Cahyono

Email: bambangkun@gmail.com

\begin{abstract}
Indonesia is the largest archipelagic country in the world that has become one of the main routes in international marine trade by contributing $40 \%$ of all international marine trade routes. The importance of waterways in international trading demands the existence of nautical chart for navigation. Time after time, the sea changes, therefore nautical chart needs to be update especially on the area that has a high marine traffic density such as Java Sea which currently has developed an electronic map for navigation, however paper charts are still needed for planning shipping line, the navigation on small boats and backup of charts on large ships. The aim to be achieved from this research is the availability of the latest paper chart which is appropriate with IHO standard S-4, INT1 (symbols, abbreviations and terms used on charts), INT2 (the boundary lines, gradient, grid and linear scale) and Chart Number 1. Updating chart number 69 was created by using data Electronic Navigation Chart (ENC) Northern part of Central Java region, data raster paper chart number 69 the ninth edition of the second expenditure, survey data 2017 in Cirebon and the Eastern part of Java Sea and Indonesian Notice to Mariners number 11-29 year 2017. Data obtained from the Pusat Hidrografi dan Oseanografi TNI-AL. The software used in production of nautical chart is Paper Chart Composer (PCC). Then it was added the updated data and information to the chart. The result of production a chart were corrected using digital and manual quality control analysis to eliminate errors in the process of production chart. As a result of updating nautical chart number 69 is that some of the objects that had been corrected have errors so it needs to be repaired until no more errors occur. The updating paper chart was already matched to standard IHO S-4 and INT1. The visualization of paper chart in accordance with the standard IHO INT2 and Chart number 1. The availability of paper chart number 69 with the update of data on the area of the Java Sea has been accomplished and can be used by mariner to navigation.
\end{abstract}

(C) Author(s) 2018. This is an open access article under the Creative Commons Attribution-ShareAlike 4.0 International License (CC BY-SA 4.0).

\section{Pendahuluan}

\subsection{Latar Belakang}

Indonesia merupakan negara kepulauan terbesar di dunia dengan luas lautan lebih dari 2/3 dari seluruh wilayah teritorial negara (BIG, 2013). Letak geografis Indonesia yang berada di antara dua benua membuat Indonesia menjadi jalur dalam perdagangan internasional melalui laut dari Australia ke Asia dan Eropa. Menurut
Laksamana TNI Ade Supandi, Kepala Staf TNI Angkatan Laut, laut Indonesia sangat penting bagi dunia internasional. Hal tersebut dikarenakan $40 \%$ perdagangan internasional melalui perairan laut Indonesia (Detik, 2016).

Pentingnya perairan dalam perdagangan internasional menuntut adanya peta laut untuk keperluan navigasi bagi pelayar. Seiring berjalannya waktu, kondisi laut mengalami perubahan yang dapat membahayakan navigasi pelayaran. Oleh karena itu perlu adanya 
pemutakhiran pada data peta laut terhadap perubahanperubahan yang terjadi secara akurat dan teliti terutama pada daerah yang memiliki kepadatan lalu lintas laut tinggi.

Salah satu perairan yang memiliki kepadatan lalu lintas laut yang tinggi adalah Laut Jawa. Laut Jawa merupakan wilayah padat lalu lintas dengan densitas lebih dari 340.000 kapal setiap $5 \mathrm{~km} 2$ pada setiap rute tahun 2017. Sementara itu terdapat lebih dari sepuluh rute kapal yang berada di Laut Jawa baik dari Barat-Timur maupun UtaraSelatan (Marinetraffic, 2017). Di sisi lain, pemerintah juga merencanakan adanya tol laut di perairan Indonesia yang melewati Laut Jawa. Selain itu pada peta wilayah Laut Jawa juga masih terdapat data pengukuran tahun 18811919 yang digunakan dalam pembuatan petanya. Data tersebut merupakan data hidrografi Belanda yang sudah terlalu lama sehingga perlu dilakukan pembaruan pada data peta agar sesuai dengan kondisi sebenarnya di laut supaya tidak membahayakan dalam pelayaran mengingat kepadatan lalu lintas Laut Jawa yang tinggi.

Perkembangan teknologi yang cepat membuat peta laut yang dikembangkan tidak hanya peta kertas melainkan peta elektronik yang digunakan pada kapal-kapal besar. Meskipun demikian, peta kertas masih dibutuhkan untuk keperluan perencanaan alur pelayaran, navigasi pelayaran pada kapal-kapal kecil maupun cadangan peta laut pada kapal besar apabila terjadi kerusakan pada kapal misalnya kapal mengalami blackout. Dengan dua tipe peta tersebut, International Hydrographic Organization (IHO) menetapkan standar mengenai transfer data pada data hidrografi digital yaitu S-57 untuk memudahkan pertukaran data antara data peta kertas dan ENC. Selain standar yang telah disebutkan, terdapat standar lain dalam pembuatan peta laut yaitu ketetapan peta laut internasional (INT) dan standar peta laut IHO diatur dalam standar S-4 tahun 2017. Kegiatan aplikatif ini dilakukan agar tersedianya peta laut terbaru yang sesuai dengan standar IHO sebagai sarana navigasi laut.

\subsection{Tujuan}

Tujuan dari kegiatan aplikatif ini adalah menyediakan peta laut dalam format cetakan atau peta laut kertas (paper chart) yang terbaru pada tahun 2017 sesuai standar IHO berupa S-4, INT1 (Simbol, singkatan dan istilah yang digunakan dalam peta laut), INT2 (Garis batas, graduasi, grid dan skala linier) dan Peta Laut Nomor 1 (Layout peta, legenda, simbolisasi dan warna).

\subsection{Landasan Teori}

\subsubsection{Peta Laut}

Pengertian peta laut menurut IHO (2010) adalah peta yang secara khusus dibuat untuk kepentingan navigasi laut, menampilkan data di antaranya data kedalaman, sifat dasar laut, elevasi, konfigurasi dan karakteristik dari pantai, bahaya dan bantuan dalam navigasi. Sesuai dengan pengertian tersebut, peta laut berfungsi memberikan gambaran informasi secara grafis kepada pelaut mengenai navigasi laut yang aman. Terdapat dua jenis peta laut yang tersedia yaitu peta laut kertas dalam bentuk analog dan peta laut elektronik dalam bentuk digital.
Lembaga internasional yang bertanggung jawab dalam menentukan standar untuk peta laut adalah International Hydrographic Organization (IHO). Ketetapan peta laut internasional (INT) dan standar peta laut IHO diatur dalam standar S-4 tahun 2017 dan S-57 tahun 2016. . S-4 didukung oleh sejumlah spesifikasi teknis antara lain INT1 (Simbol, singkatan dan istilah yang digunakan dalam peta laut), INT2 (Garis batas, graduasi, grid dan skala linier). Selain itu juga terdapat standar lain yang telah ditetapkan IHO. Di Indonesia, lembaga nasional yang berwenang dalam pembuatan dan penerbitan peta laut adalah Pusat Hidrografi dan Oseanografi TNI Angkatan Laut (Pushidrosal).

\subsubsection{Datum Geodetik}

Datum geodetik merupakan himpunan parameter dan konstanta yang mengimplikasikan hubungan (kedudukan dari orientasi spasial) elipsoid acuan terhadap bumi fisis atau geoid. World Geodetic System (1984) (WGS84) harus digunakan sebagai dasar sistem referensi seluruh dunia untuk peta laut hingga terdapat alternatif datum geodetik yang diadopsi oleh organisasi internasional terkait untuk digunakan sebagai sistem referensi geodetik internasional untuk pekerjaan kartografi baik di area darat maupun laut (IHO, 2017). ). Datum geodetik digunakan sebagai referensi posisi horizontal dan posisi vertikal.

Menurut IMO Safety of Navigation Circular 213, datum horizontal adalah sistem referensi untuk menentukan posisi horizontal (x, y) di permukaan bumi (IHO, 2017). Referensi vertikal pada peta adalah berdasarkan bidang permukaan laut yang nilainya diperoleh dari pengamatan pasang surut air laut. Pada peta laut, referensi tinggi yang digunakan adalah permukaan air rendah (chart datum) (IHO, 2006).

\section{I.3.3 Sistem Koordinat}

Suatu sistem koordinat titik di permukaan bumi posisinya ditentukan oleh pemotongan dua buah garis lengkung bumi yaitu garis paralel (latitude) dan garis meridian (longitude) (Soendjojo \& Riqqi, 2017). Origin 0 sistem koordinat geodetik (datum geodetik) biasanya didefinisikan berimpit dengan pusat massa bumi. (Prihandito, 2010).

Sistem koordinat titik di permukaan bumi berbeda dengan sistem koordinat titik di peta. Pemindahan letak titik-titik pada permukaan bumi ke bidang datar disebut proyeksi peta. Sistem proyeksi peta yang paling sering digunakan pada peta laut adalah proyeksi Mercator karena mempunyai fitur navigasi yang berguna dimana garis loxodromes atau rhumb digambarkan sebagai garis lurus, yaitu semua garis meridian berpotongan pada sudut yang sama.

\section{I.3.4 Kategori Skala Navigasi}

Pada peta laut, skala peta ditentukan oleh jenis navigasi yang direncankana, sifat daerah yang tercakup dan kuantitas informasi yang dimasukkan. Hal ini bertujuan untuk menunjukkan jenis peta dibandingkan dengan skala peta dimana setiap area mungkin memiliki perbedaan. Secara umum, pembagian skala pada peta laut dibagi 
menjadi skala kecil, skala menengah dan skala besar. Skala kecil terdiri dari skala navigasi overview dan skala menengah terdiri dari skala navigasi general dan coastal, sedangkan skala besar terdiri dari approach, harbour dan berthing (IHO, 2017).

\section{I.3.5 Diagram Sumber}

Istilah diagram sumber mencakup grafik yang menunjukkan batas-batas sumber data yang digunakan dan informasi lain berkaitan dengan sumber data. Tujuan dari diagram sumber adalah untuk memandu dan membantu navigator merencanakan "operasi navigasi" termasuk perencanaan rute-rute baru pada tingkat kepercayaan yang memadai dan keakuratan kedalaman yang dipetakan maupun posisi navigator. Terdapat dua jenis diagram sumber untuk meringkaskan sumber hidrografi yaitu diagram sumber konvensional dan diagram ZOC. Diagram sumber konvensional memberikan informasi tentang sumber survei dimana pelaut dapat menyimpulkan tingkat kepercayaan data kedalaman peta laut. Diagram ZOC merupakan sumber diagram yang memberikan informasi lebih kualitatif dari sumber informasi. Melalui diagram ZOC memungkinkan pelaut untuk menilai kualitas data hidrografi dari bagan kompilasi (IHO, 2017).

\section{I.3.6 Generalisasi}

Generalisasi adalah pemilihan dan penyederhanaan dari penyajian unsur-unsur pada peta dan selalu harus berhubungan dengan skala dan tujuan dari peta itu sendiri. Penggambaran pada skala peta yang lebih kecil akan melibatkan adanya generalisasi (Prihandito, 1989). Pada pembuatan peta laut, panduan dalam generalisasi fitur tertentu dimasukkan dalam banyak spesifikasi. Ketika dilakukan penurunan skala pada peta laut, generalisasi yang dilakukan akan memberikann beberapa efek . (IHO, 2017).

\section{I.3.7 Penamaan dan Penomoran Peta Laut}

Penomoran dan penamaan suatu peta dibuat untuk kemudahan bagi pemakai dan sistem penyimpanan peta. Setiap negara mempunyai sistem penomoran masingmasing. Oleh karena itu nomor peta umumnya unik.

Penomoran peta laut kertas dengan seri peta laut nasional merupakan kebijakan nasional. Nomor peta laut nasional harus dicetak hitam dan diletakkan di sudut kanan bawah dan sudut kiri atas peta laut. Sementara untuk peta laut internasional, nomor peta laut harus ditunjukkan dalam warna magenta dengan huruf arab dan diawali "INT". Nomor peta internasional harus diletakkan di samping atau di atas dari nomor peta nasional (IHO, 2017). Sistem penomoran peta laut kertas di Indonesia diatur oleh Pushidrosal. Indonesia hanya memiliki nomor peta laut nasional dan tidak mengeluarkan nomor peta internasional pada peta lautnya.

Sistem penomoran untuk peta laut kertas dan ENC berbeda. Pada peta laut kertas tidak ada ketentuan penomoran yang baku, peta laut baru akan diberi nomor berdasarkan nomor akhir peta laut kertas yang tersedia tanpa melihat lokasi maupun skala dari peta baru tersebut.
Sementara untuk ENC, penomoran dibuat berdasarkan gabungan dari kode negara pembuat, usage band (cell) dan nomor peta kertasnya yang terdiri dari 2 digit kode negara, 1 digit usage band dan 5 digit nomor peta. Nomor dari cell ENC diatur berdasarkan dari rentang skala peta.

\section{I.3.8 Updating Data}

Informasi mengenai setiap perubahan pada peta laut dan publikasinya harus diumumkan secara teratur melalui berita pelaut dan melalui pembaruan peta laut dan publikasinya. Hal tersebut penting dalam pelayanan pemeliharaan peta laut yang harus disediakan oleh layanan hidrografi nasional yang memproduksi peta laut dan publikasi kelautan. Informasi perubahan baik kedalaman kanal dermaga, bahaya baru (seperti bangkai kapal, gosong) dan informasi lain yang berada disekitar pelabuhan, serta informasi mengenai perairan pesisir yang diperoleh dari kapal-kapal yang berlayar di perairan nasional harus dimasukkan juga ke dalam peta laut terkait. Selain itu, informasi tersebut juga harus berada di dalam berita pelaut dalam kasus ini Berita Laut Indonesia (BPI). Perubahan darurat dan berpengaruh secara signifikan pada navigasi harus juga disiarkan untuk memastikan informasi tersebut terdistribusi secara cepat dan luas kepada semua pelaut sesuai dengan kesepakatan yang dibuat oleh IMO dan IHO (IHO, 2016).

\subsubsection{Produksi, maintenance dan distribusi}

Dunia maritim yang digambarkan dalam peta laut tidak bersifat statis, sebagai contoh: metode survei semakin canggih memberikan rincian lebih akurat batimetri, nilai kedalaman yang di beberapa daerah terus berubah; jalur pengiriman kapal pada dam berubah; port dikembangkan; rambu untuk navigasi yang berubah dan dipindahkan; keselamatan dan lingkungan mengakibatkan langkah pembuatan rute baru dan pembatasan navigasi; meningkatkan eksploitasi sumber daya alam; penghalang navigasi yang baru ditemukan. Semua informasi tersebut harus diumumkan kepada pelaut. Metode dalam memasukkan informasi baru ke dalam peta laut kertas antara lain (IHO, 2017):

1. Memperbarui peta kertas dengan Berita Pelaut Indonesia.

2. Edisi baru dalam peta kertas.

3. Perubahan dengan pendahuluan atau sementara dalam BPI adalah perkembangan informasi untuk peta kertas.

\section{I.3.10 CARIS PCC (Paper Chart Composer)}

CARIS PCC merupakan alat kompilasi pembuatan peta kertas untuk sebuah organisasi yang mengolah dan memelihara peta kertas. PCC memungkinkan memindahkan data dari produksi desktop ke basisdata dengan efisien. Sistem dari PCC adalah sistem stand-alone yang menyediakan satu tempat untuk pembuatan dan pemeliharaan dari setiap produksi peta kertas. Data vektor peta laut yang dapat dibuka pada PCC diantaranya ENC, file hob atau file CARIS, dengan data tersebut dapat digunakan untuk membuat peta kertas dengan panel dan sheet 


\section{I.3.11 Kartografi Laut}

Kartografi merupakan suatu disiplin ilmu yang berhubungan dengan visualisasi dari informasi geospasial. Lingkup pekerjaan kartografi dimulai dari pembuatan desain peta (seperti pembuatan simbol peta, tata letak peta, penggambaran dan pemilihan nama-nama geografis, proses produksi). Kemudian dilanjutkan dengan pengolahan data seperti penentuan sistem proyeksi peta, penggambaran, pemilihan metode penyajian, kontruksi peta. Terakhir adalah proses penyajian hasil akhir (Soendjojo \& Riqqi, 2017). Dalam kartografi laut, simbol, tata letak maupun sistem proyeksi telah ditetapkan oleh IHO dalam Peta Laut Nomor 1.

\section{Data dan Metodologi}

\subsection{Data dan Lokasi}

Data yang digunakan pada kegiatan aplikatif ini meliputi:

1. Data ENC wilayah peta laut nomor 69 daerah Jawa Tengah bagian Utara yang didapatkan dari data ENC pada cell nomor ID200068, ID202862, ID202797, ID 202796 dalam format *.hob.

2. Data raster peta laut nomor 69 pengeluaran kesembilan tahun 2013 cetakan kedua dikoreksi sampai dengan BPI nomor 10 tahun 2017.

3. Data citra GEOTIFF daerah Jawa bagian Tengah.

4. Data survei pada wilayah Cirebon dan Laut Jawa bagian Timur tahun 2017.

5. BPI (Berita Pelaut Indonesia) nomor 11 sampai dengan 29 tahun 2017.

6. Dokumen-dokumen spesifikasi produk peta laut diantaranya S-4, S-57, INT1 (simbol, singkatan dan istilah yang digunakan dalam peta laut), INT2 (garis batas, graduasi, grid dan skala linier) dan Peta Laut Nomor 1 (layout peta, legenda, simbolisasi dan warna).

Lokasi kegiatan ini berada di Jawa bagian Tengah pada koordinat $107^{\circ} 40^{\prime} 04.966^{\prime \prime} \mathrm{BT}$ - $111^{\circ} 39^{\prime} 48.13^{\prime \prime} \mathrm{BT}$ dan 5018'59.671" LS - 8 8 $^{\prime} 48^{\prime}$ 58.518” LS seperti yang ditunjukkan pada Gambar 2.1.

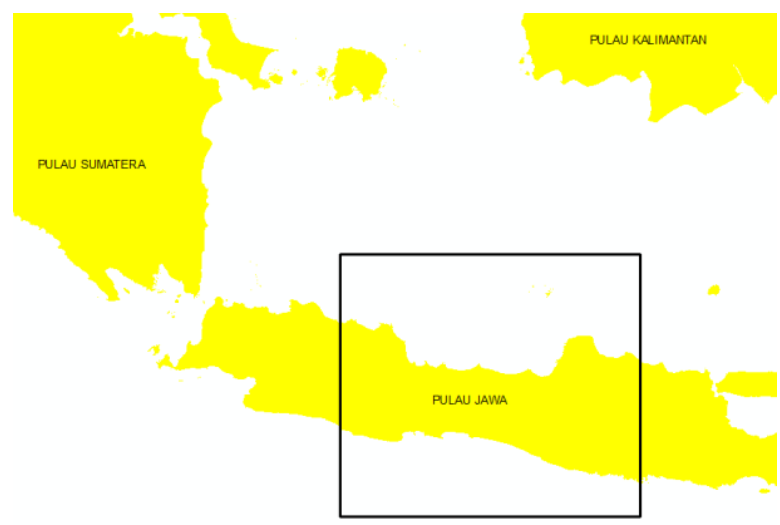

Gambar 2.1. Cakupan area pembaruan peta laut

\subsection{Metodologi}

Metodologi kegiatan aplikatif ini dapat dilihat pada Gambar 2.2.

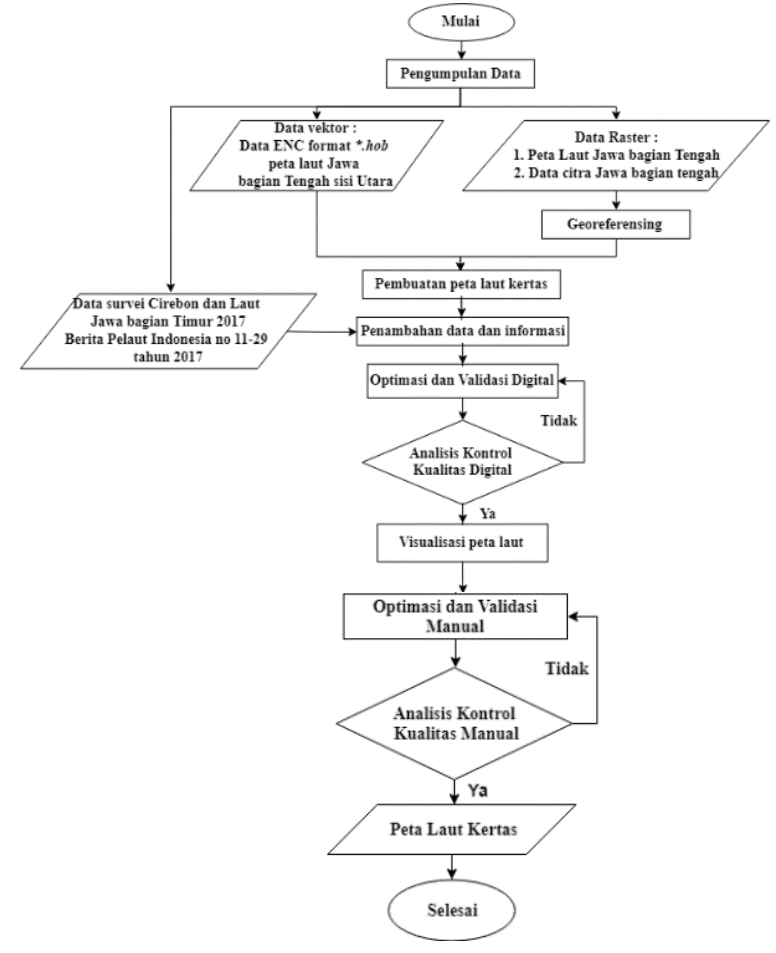

Gambar 2.2 Diagram alir pekerjaan

\subsubsection{Pengumpulan Data}

Peta laut nomor 69 merupakan peta laut Jawa bagian Tengah yang dibuat pertama kali pada Juni 1907. Pembaruan peta terakhir dilakukan pada tahun 2017 yang merupakan peta cetakan kedua dari pengeluaran kesembilan tahun 2013 dengan koreksi BPI sampai dengan nomor 10 tahun 2017. Pembaruan kembali dilakukan karena terdapat data survei yang dilakukan tahun 2017 pada wilayah Cirebon dan Laut Jawa bagian Timur. Data yang digunakan pada pembaruan peta antara lain data ENC peta 69 wilayah Jawa Tengah bagian Utara yang didapatkan dari data ENC dalam format *.hob, data raster peta nomor 69 edisi terbaru dimana data tersebut digunakan untuk membuat peta dasar pada bagian yang tidak tercakup pada data ENC sebelum updating data. Selain itu, digunakan data citra Jawa bagian Tengah untuk pengkoreksian peta dasar. Data lain yang digunakan untuk pembaruan peta selain data survei yaitu BPI nomor 11 sampai dengan nomor 29 tahun 2017.

\subsubsection{Georeferencing}

Proses georeferencing dilakukan pada data raster yang digunakan dalam kegiatan ini. Hal ini dilakukan untuk memberikan sistem koordinat pada data tersebut sesuai dengan ketentuan IHO. Pada saat dilakukan pemasukan data nilai dari Root Mean Square Error (RMSE) harus kurang dari 1. Hal ini dilakukan agar ketelitian koordinat hasil dari georeferencing baik. Apabila nilai dari RMSE lebih dari 1 maka proses georeferencing harus diulang.

\subsubsection{Pembuatan Peta Laut}

Pada pembuatan peta laut, terlebih dahulu dilakukan perekaman data untuk mengubah data format raster 
menjadi format vektor dengan menggunakan PCC. Selain itu juga dilakukan pengubahan data ENC format *.hob yang ada menjadi satu data pada PCC. Proses perekaman data dimulai dengan pembuatan lembar kerja baru dalam bentuk panel pada perangkat lunak PCC. Panel yang telah dibuat berisi data ENC format *.hob cell ENC Jawa bagian Tengah sisi Utara, sedangkan data bagian Selatan belum ada. Oleh karena itu, perlu dilakukan digitasi pada data sisi bawah Jawa bagian Tengah.

Proses digitasi dilakukan dengan membuat fitur yang terdiri dari titik, garis, luasan dan titik kedalaman. Pada pembuatan fitur ini perlu mengetahui fitur yang ada dan singkatan dari fitur tersebut sesuai dengan standar S-57.

\subsubsection{Penambahan Data dan Informasi}

Proses penambahan data dilakukan setelah ditemukan data baru yang berhubungan dengan peta laut nomor 69 Data baru pada peta laut nomor 69 antara lain data survei pada wilayah Cirebon dan Laut Jawa bagian Timur pada tahun 2017 serta data BPI. Data survei pada wilayah Cirebon dan Laut Jawa bagian Timur dibuat dalam skala yang lebih besar. Oleh karena itu, perlu dilakukan generalisasi pada saat penambahan data dengan data survei. Informasi data ringkasan BPI berada di balik leger yang merupakan dokumen yang memuat data dan informasi mengenai perkembangan peta. Sementara penambahan informasi yang dimaksudkan pada tahap ini berupa diagram kompilasi dan mawar kompas.

\subsubsection{Optimasi dan Validasi Digital}

Pada saat proses perekaman data baik pada digitasi maupun pengisian atribut dimungkinkan terdapat kesalahan. Kesalahan-kesalahan tersebut dapat mengurangi kualitas data vektor dari data digital maupun pada hasil cetak data sehingga harus dihilangkan. Proses analisis kontrol kualitas terdiri dari tujuh belas pengecekan yang dilakukan baik pada fitur maupun atribut. Pengecekan tersebut yaitu duplicate objects, prohibited objects, prohibited primiteves, invalid attributes, mandatory attributes, invalid geometry, overlapping area, overlapping edges, intersecting edges, redundant edges points and soundings, edges with redundant vertices, edges to merge, lines to merge, areas to merge, points insides areas, lines bordering areas, presentation conflicts.

\subsubsection{Visualisasi Peta}

Visualisasi peta dibuat berdasarkan Peta Laut Nomor 1. Posisi dari layouting peta telah ditetapkan oleh IHO pada Peta Laut Nomor 1. Sementara untuk border dari peta ditentukan berdasarkan standar IHO INT 2 dimana tipe border akan berbeda sesuai dengan skala yang digunakan. Pada peta laut nomor 69 yang merupakan peta dengan skala 1:500.000, border yang dipakai adalah border J.

\subsubsection{Optimasi dan Validasi Manual}

Optimasi dan validasi dilakukan untuk menghindari kesalahan yang tidak bisa dicek pada perangkat lunak seperti ukuran standar fitur, nama suatu daerah maupun kekurangan data lain. Pada saat pengecekan secara manual sumber yang dipakai untuk pengecekan tidak hanya leger, BPI maupun data survei terbaru melainkan juga peta-peta laut dengan skala lebih besar pada daerah Jawa bagian Tengah. Sumber lain yang dipakai untuk pengecekan adalah peta skala besar pada lingkup Jawa bagian Tengah. Pengecekan lain yang dilakukan adalah mengecek kesesuaian dari simbol, singkatan dan label yang tercetak dengan standar yang telah ditetapkan. Selain itu, juga perlu diperhatikan posisi dari anotasi fitur supaya informasi dari fitur yang ada tidak ambigu.

\section{Hasil dan Pembahasan}

3.1 Hasil Penambahan Data dan Informasi

Laut Jawa merupakan salah satu laut di Indonesia dengan kepadatan lalu lintas pelayaran yang tinggi sehingga perlu dilakukan pembaruan peta laut dengan kualitas data hidrografi yang lebih baik untuk keamanan navigasi pelayaran. Data pembaruan untuk peta laut didapatkan dari proses survei kelapangan dengan melakukan pengukuran secara langsung maupun BPI. Dari proses survei, dihasilkan lembar lukis teliti yang dibuat dalam skala yang besar. Oleh karena itu pada saat pembaruan dari peta laut perlu dilakukan generalisasi. Generalisasi pada peta laut diantaranya sounding selection dan penyederhanaan simbol objek. Sounding selection merupakan generalisasi dengan melakukan pemilihan titik kedalaman. Pada saat sounding selection penting dalam menentukan titik kedalaman yang akan ditampilkan dimana kedalaman yang ditampilkan harus selalu disertai nilai kedalaman terdangkal pada suatu area. Hal ini berkaitan dengan tujuan dari pembuatan peta yaitu untuk keselamatan navigasi. Selain itu, juga perlu diperhatikan tampilan dari peta laut agar tetap rapi dan informatif.

Penyederhanaan objek yang dilakukan pada generalisasi ini adalah penyederhanaan bentuk objek rambu (beacon). Generalisasi rambu pada peta laut dilakukan dengan mengubah simbol rambu jenis apapun menjadi bentuk bintang. Generalisasi ini dilakukan berdasarkan IHO S-4 bagian B457.2 dimana untuk peta dengan skala kecil maka beacon harus diberikan dalam simbol berupa suar sesuai dengan P1 pada INT1. Dalam P1, simbol yang dimaksudkan adalah simbol bintang. Pembaruan peta juga dilakukan menggunakan BPI dengan penambahan data BPI nomor 11 hingga 29.

\subsection{Hasil Optimasi dan Validasi Digital}

Pada proses pengecekan data secara digital terdapat tujuh belas pengecekan kualitas data dengan validasi PCC. Hasil dari cek kesalahan yang dilakukan akan menjelaskan mengenai tingkat kesalahan, letak kesalahan dan solusi untuk memperbaiki kesalahan tersebut. Dari 17 pengecekan kesalahan yang dilakukan terdapat 7 pengecekan yang mendapatkan hasil tidak terdapat kesalahan, sementara 10 kesalahan lain ditemukan kesalahan pada data digital dan telah dilakukan perbaikan.

\subsection{Hasil Visualisasi Peta}

Pada peta laut, penyajian peta telah diatur pada standar S-4 tahun 2017 sehingga dalam penentuan simbol, singkatan dan istilah yang ditampilkan pada peta laut 
harus sesuai dengan standar yang telah ditetapkan. Selain itu, penamaan dari suatu fitur termasuk toponimi, deskripsi dan singkatan juga harus diatur sedemikian rupa agar tidak menutupi fitur penting lainnya dan tidak ambigu sesuai dengan kaidah kartografi. Hal lain yang perlu diperhatikan yaitu keindahan tampilan dari peta yang disajikan.

Informasi yang harus disajikan pada peta adalah judul peta, nomor peta dan catatan kecil seperti catatan publikasi, catatan hak cipta, catatan koreksi kecil, sumber diagram data dan lain sebagainya. Pada PCC telah dibuat format layouting untuk peta laut Indonesia sesuai dengan Peta Laut Nomor 1 sehingga pada pembuatannya hanya perlu melakukan penambahan format layouting tersebut.

\subsection{Hasil Optimasi dan Validasi Manual}

Pada kegiatan ini hanya dilakukan dua tahap validasi yaitu validasi pertama dan kedua. Hasil koreksi pada validasi pertama ditemukan banyak kesalahan seperti kurangnya data yang dimasukkan seperti bom laut, pipa dan kota; ketidaksesuaian ukuran dan simbol fitur dan kesalahan layouting peta (lihat gambar 3.1).

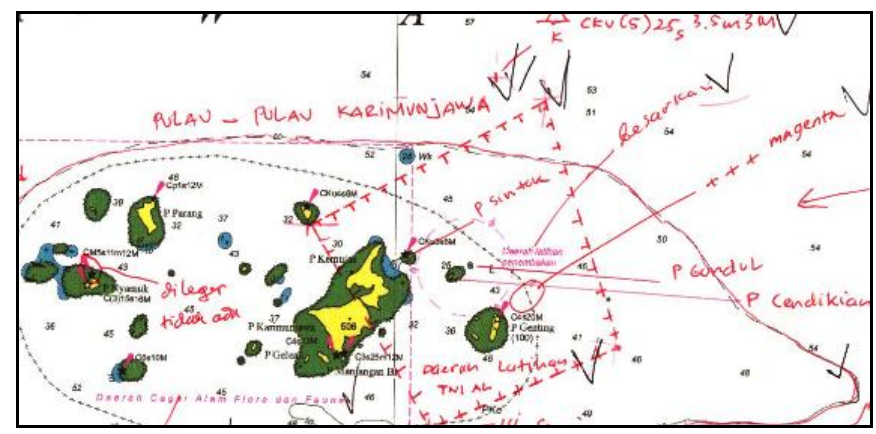

Gambar 3.1 Hasil kesalahan yang ditemukan pada validasi pertama

Dari validasi pertama dilakukan perbaikan peta laut sesuai dengan kesalahan-kesalahan yang ditemukan. Hasil dari perbaikan pada validasi pertama dapat dilihat pada Gambar 3.2 yang telah diubah sesuai dengan keterangan kesalahan yang telah ditemukan. Kemudian dilakukan validasi yang kedua pada hasil peta perbaikan validasi pertama untuk melihat apakah terdapat kesalahan lain yang sebelumnya tidak terlihat dan untuk mengecek hasil perbaikan dari kesalahan sebelumnya yang telah didapatkan.

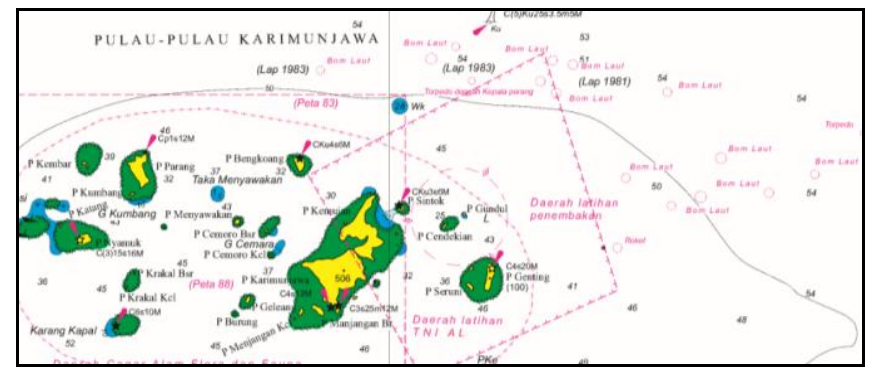

Gambar 3.2 Hasil perbaikan kesalahan validasi pertama
Pada validasi kedua masih ditemukan beberapa kesalahan diantaranya belum ditariknya kontur 300 meter pada peta laut, kesalahan informasi suar dan garis kontur yang kasar. Dari Gambar 3.3 dapat dilihat bahwa hasil perbaikan sebelumnya telah benar dan tidak ada kesalahan lain selain perbaikan pada garis kontur yang masih kasar yang ditandai oleh korektor dengan lingkaran merah. Setelah dilakukan pengecekan kesalahan pada validasi kedua ini, kembali dilakukan perbaikan sesuai dengan kesalahan yang ditandai oleh korektor. Hasil dari validasi manual kedua yang dilakukan ini merupakan peta hasil akhir pembaruan peta laut pada kegiatan aplikatif ini.

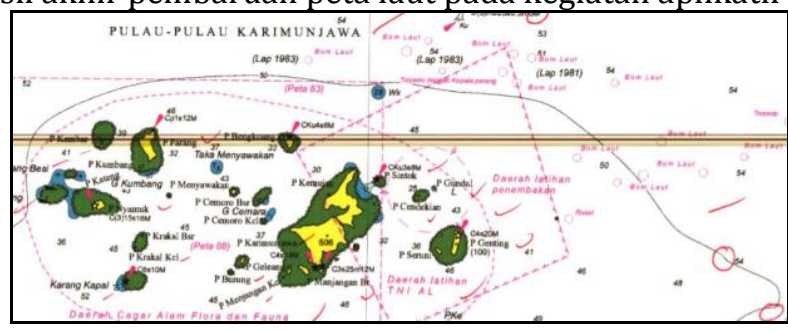

Gambar 3.3 Hasil kesalahan validasi kedua

\subsection{Hasil Pembuatan Peta Laut}

Hasil dari pembaruan peta Laut Jawa bagian Tengah dapat dilihat pada Gambar 3.4. Hasil pembaruan ini merupakan edisi baru dari peta laut nomor 69. Hal ini berdasarkan IHO S-4 bagian B600 mengenai perawatan peta dimana peta yang mengalami mengalami perubahan datanya lebih dari $25 \%$ dan terdapat perubahan simbol (modernisasi simbol) dapat dibuat peta edisi baru. Dalam pembaruan peta terdapat beberapa perubahan pada peta baru sesuai dengan data survei dan data BPI yang dimiliki. Wilayah pembaruan dari data survei tidak lebih dari $25 \%$ dapat dilihat pada Gambar 3.5 dimana data survei mencakup wilayah Cirebon dan Laut Jawa bagian Timur yang berada di sebelah Selatan pulau-pulau Karimunjawa namun terdapat perubahan simbol (modernasisasi simbol) yaitu titik dasar (basepoint) dan rel kereta api.

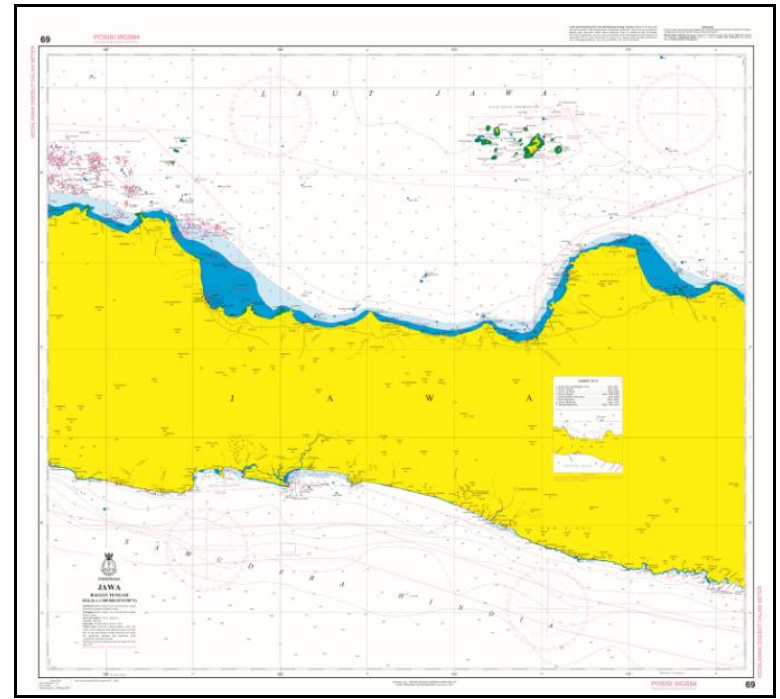

Gambar 3.4 Hasil pembaruan peta laut kertas 


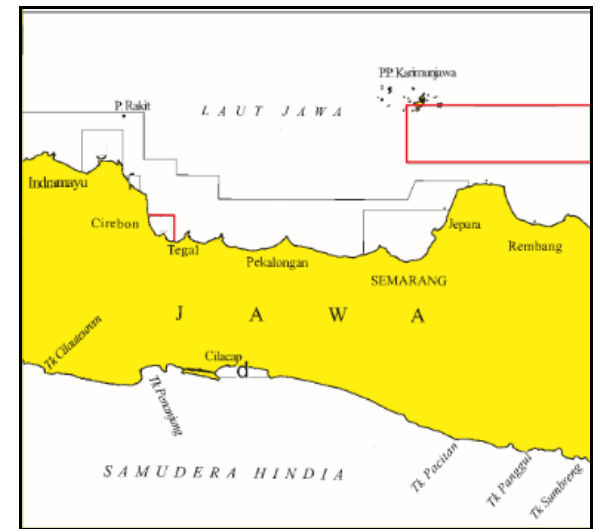

Gambar 3.5 Wilayah pembaruan peta laut nomor 69 dari data survei

Perubahan simbol titik dasar yang sebelumnya merupakan simbol bintang dalam lingkaran merupakan simbol yang dibuat untuk titik dasar sesuai kebijakan Pushidrosal seperti Gambar 3.6 (a) menjadi simbol lingkaran magenta merupakan simbol titik dasar sesuai dengan peraturan IHO INT1 seperti pada Gambar 3.6 (b). Perubahan simbol dikarenakan pihak Pushidrosal memutuskan untuk menggunakan simbol sesuai dengan IHO pada titik dasar.

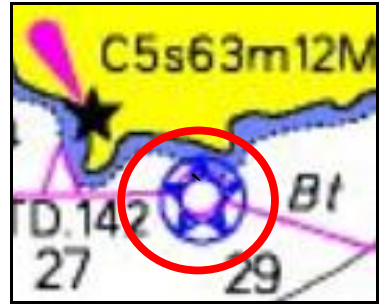

(a)

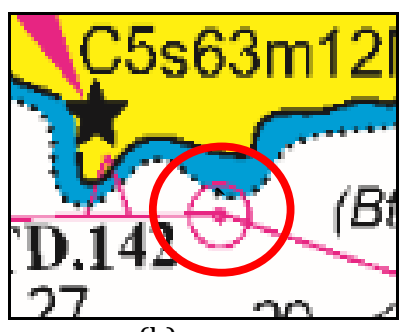

(b)
Gambar 3.6 Simbol titik dasar

Perubahan simbol lainnya yaitu simbol rel kereta api yang sebelumnya disimbolkan seperti Gambar 3.7, kemudian menjadi seperti Gambar 3.8. Perubahan simbol kereta dilakukan karena pada perangkat lunak PCC tidak terdapat simbol fitur rel kereta api seperti simbol pada peta yang lama sehingga menggunakan simbol rel kereta api yang berbeda. Hal ini dapat dilakukan karena IHO menetapkan tiga simbol untuk rel kereta api yang ditunjukkan pada Gambar 3.9 sehingga dalam penggunaannya pada peta laut bisa memilih salah satu simbol untuk rel kereta api.

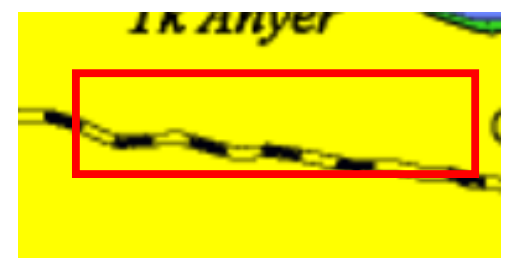

Gambar 3.7 Simbol rel kereta api lama

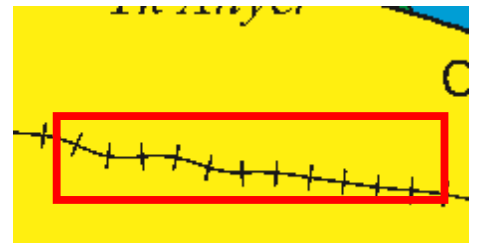

Gambar 3.8 Simbol rel kereta api baru

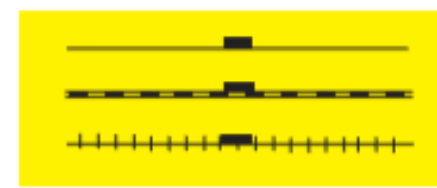

Gambar 3.9 Simbol rel kereta api sesuai IHO

Setelah dilakukan proses pembaruan seperti digitasi, penambahan data dan informasi dan validasi pada peta laut nomor 69 area Laut Jawa terdapat beberapa perubahan pada peta laut terbaru tahun 2017 diantaranya perubahan nilai kedalaman, perubahan kontur dan perubahan lain pada saat penambahan BPI .

Perubahan nilai dan penulisan kedalaman berdasarkan peraturan B 412.4 pada IHO S-4 dimana diperlukan untuk menarik perhatian pelaut pada fakta mengenai nilai kedalaman yang dimasukkan tidak dapat diandalkan seperti dalam beberapa hal dikarenakan data berasal dari survei lead line, kurangnya data sonar ataupun wilayah yang dicurigai seperti memiliki anomali kedalaman maka nilai kedalaman harus dituliskan tegak. Penulisan nilai kedalaman yang sebelumnya tegak seperti pada Gambar 3.10 menjadi miring seperti yang ditunjukkan pada Gambar 3.11.

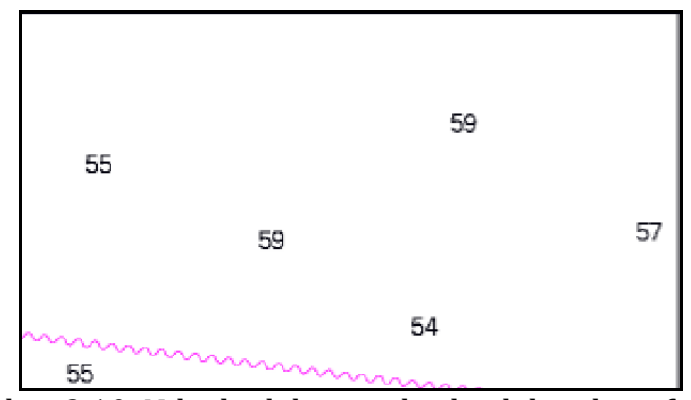

Gambar 3.10 Nilai kedalaman ditulis dalam huruf tegak

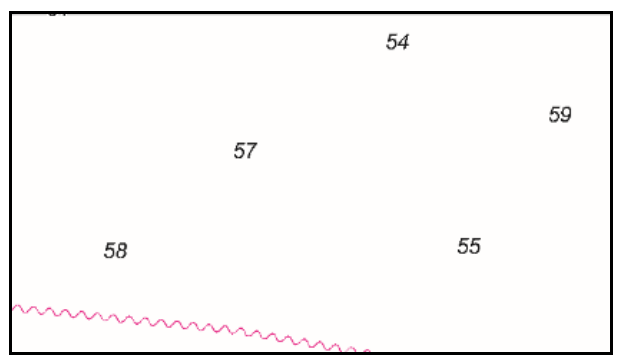

Gambar 3.11 Nilai kedalaman ditulis dalam huruf miring

Perubahan garis kontur yang ditunjukkan pada Gambar 3.12 dan Gambar 3.13 dikarenakan nilai kedalaman pada hasil pengukuran survei pada tahun 2017 berbeda dengan nilai kedalaman hasil pengukuran 
sebelumnya. Pada perubahan kontur tersebut dapat dilihat kontur telah mengalamai perubahan yang cukup siginifikan dimana kedalaman pada wilayah Laut Jawa mengalami pendangkalan.

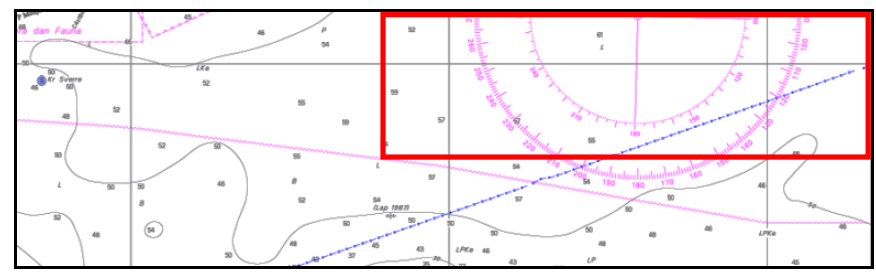

Gambar 3.12 Garis kontur pada peta edisi 9 cetakan ke-2

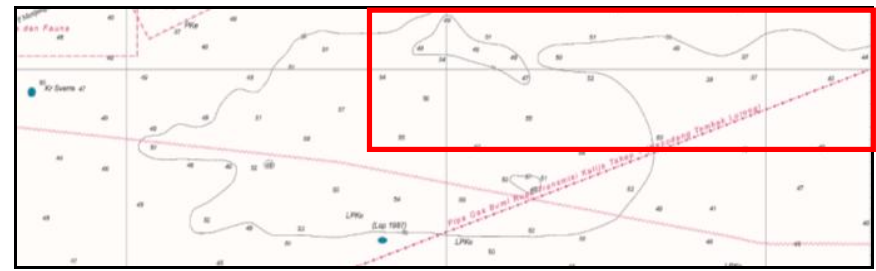

Gambar 3.13 Garis kontur pada peta edisi 10

Perubahan lain yaitu ada saat penambahan data BPI. Data BPI yang ditambahkan pada peta laut nomor 69 merupakan berita mengenai penambahan suar baru pada platform di wilayah Laut Jawa. Perubahan penambahan BPI dapat dilihat pada Gambar 3.14 dan 3.15.

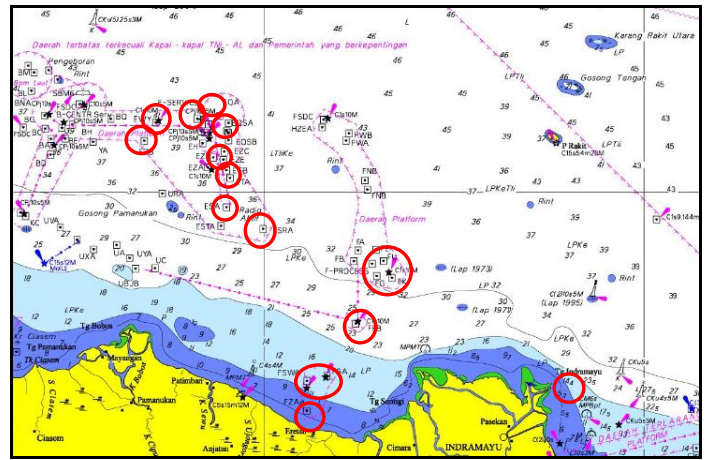

Gambar 3.14 Peta laut 69 sebelum ditambahan BPI

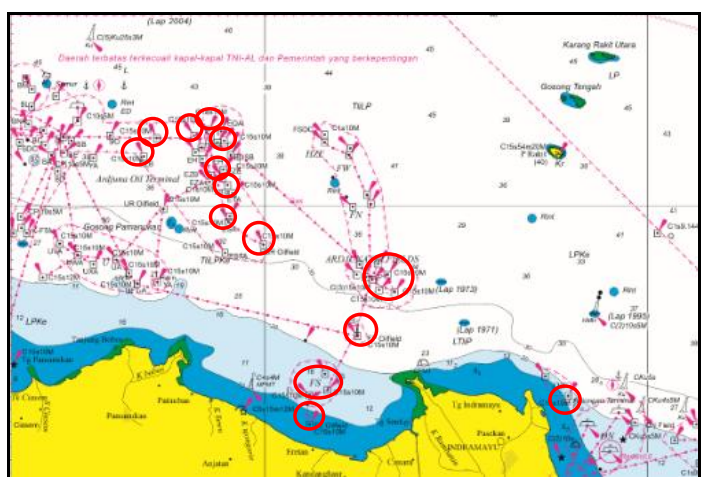

Gambar 3.15 Peta laut 69 setelah ditambahan BPI

\section{Kesimpulan}

Berdasarkan hasil kegiatan yang telah dilakukan dapat diambil kesimpulan bahwa saat ini telah tersedia peta laut kertas Jawa bagian Tengah skala 1:500.000 edisi 10 tahun 2017. Produk yang dihasilkan adalah peta laut edisi baru Jawa bagian Tengah dengan kualitas data hidrografi yang lebih baik sehingga dapat meningkatkan keamanan pelayaran navigasi pada Laut Jawa. Perubahan pada pembaruan peta diantaranya perubahan nilai dan penulisan kedalaman dimana penulisan nilai kedalamannya dalam bentuk tegak menjadi miring, perubahan garis kontur yang memberikan informasi bahwa Laut Jawa telah mengalami pendangkalan dan terdapat penambahan informasi objek yang diperoleh dari BPI nomor 11 sampai 29 tahun 2017 berupa suar.

\section{Pernyataan Konflik Kepentingan}

Penulis menyatakan tidak ada konflik kepentingan dalam artikel ini (The authors declare no competing interest).

\section{Referensi}

BIG. (2013). BIG serahkan peta NKRI kepada Kemenkokesra.http://www.bakosurtanal.go.id/berit a-surta/show/big-serahkan-peta-nkri-kepadakemenkokesra (accessed September 03, 2017)

Detik. (2016). KSAL: 40 Persen Perdagangan Dunia Lewati Laut Indonesia. https://news.detik.com /berita/3273960 /ksal-40-persen-perdagangandunia-lewati-laut-indonesia (accessed November 23, 2017)

IHO. (2006). A Manual on Technical Aspects of The United Nations Convention on The Law of The Sea. IHO Publication C-51, International Hydrographic Bureau, Monaco.

IHO. (2010). Facts About Electronic Charts and Carriage Requirements. IHO Publication S-66, International Hydrographic Bureau, Monaco.

IHO. (2016). The Need for National Hydrographic. IHO Publication M-2, International Hydrographic Bureau, Monaco.

IHO. (2017). Regulations for International (INT) Charts and Chart Specifications of the IHO. IHO Publication S-4, International Hydrographic Bureau, Monaco.

Marinetraffic. (2017). Live Map. < https:// www.marinetraffic.com /en/ais/home/ centerx:111.6 /centery:-4.3/zoom:6 > (diakses pada 24 Februari 2018).

Prihandito, A. (1989). Kartografi. Penerbit PT Mitra Gama Widya. Yogyakarta

Prihandito, A. (2010). Proyeksi Peta. Penerbit Kanisius. Yogyakarta

Pushidrosal. (2010). Simbol dan Singkatan Peta Laut INT-1. Pusat Hidrografi dan Oseanografi TNI-AL. Jakarta

Soendjojo, H., dan Riqqi, A. (2017). Kartografi. Penerbit ITB, Bandung, Indonesia. 